\title{
Improvement of radar ice-thickness measurements of Greenland outlet glaciers using SAR processing
}

\author{
David A. BRAaten,,${ }^{1,2}$ S. Prasad GOGINEni, ${ }^{1}$ Dilip TAMmana,${ }^{1,3}$ Saikiran NAMbURI,${ }^{1}$ \\ John PADEN, ${ }^{1}$ Krishna K. GURUMOORTHY ${ }^{1}$ \\ ${ }^{1}$ Radar Systems and Remote Sensing Laboratory and ${ }^{2}$ Department of Physics and Astronomy, University of Kansas, Lawerence, KS 66045-2969, U.S.A. \\ E-mail:braaten@ukans.edu \\ ${ }^{3}$ LSI Logic Storage Systems, Inc., 3718 N. Rock Road,Wichita, KS 67226, U.S.A.
}

\begin{abstract}
Extensive aircraft-based radar ice-thickness measurements over the interior and outlet-glacier regions of the Greenland ice sheet have been obtained by the University of Kansas since 1993, with the latest airborne surveys conducted in May 2001. The radar has evolved during this period to a highly versatile system capable of characterizing ice thickness over a wide variety of ice-sheet conditions. Before 1997, the digital system was limited, only capable of storing incoherent data or coherent data with a very large number of presumed signals at a low pulse-repetition frequency. In 1998, the radar was upgraded with modern components allowing coherent data to be stored with a small number of presumed returns for 1024 range cells at a high pulse-repetition frequency. The new data on ice thickness of Greenland outlet glaciers are archived and made available to the scientific community in the form of radar echograms and derived ice thickness at http://tornado.rsl.ukans.edu/Greenlanddata.htm. The U.S. National Snow and Ice Data Center (NSIDG) also provides a link to these data, and NSIDC will eventually serve as the permanent archive of these data. Improvements in radar sensitivity in outlet-glacier regions have been achieved by collecting coherent radar data and applying various signal-processing techniques. Deep outlet-glacier channels that were previously unresolved with incoherent data can now be mapped using a coherent signal, signal conditioning and synthetic aperture radar (SAR) processing.
\end{abstract}

\section{INTRODUGTION}

Interest in the mass balance of the Greenland ice sheet sparked a multifaceted NASA research initiative consisting of coordinated surface, airborne and space-borne measurements of the ice sheet, known as the PARCA (Program for Arctic Regional Climate Assessment) initiative. For the airborne component of PARCA, the NASA P-3B Orion provides the platform to simultaneously obtain precision measurements of ice-sheet surface elevation with a laser altimeter (Krabill and others, 1995a,b), and ice-thickness measurements with an airborne radio-echo sounder operated by the University of Kansas. Both laser and radar data are tagged with precise global positioning system- (GPS-) derived position information, providing a significant improvement in geolocation of ice-thickness data over previous ice-thickness surveys. A historical summary of radars for ice-thickness measurements is given by Gogineni and others (1998).

Between 1993 and 1999, an extensive dataset of ice-elevation and ice-thickness measurements was obtained over much of the ice sheet. During this period, the radar depth sounder was incrementally upgraded to improve performance over outlet glaciers and in southern Greenland. Before 1997, the digital system using 8-bit analog/digital (A/D) converters was only capable of storing incoherent or coherent data with a very large number of presumed signals at a low pulse-repetition frequency of $2000 \mathrm{~Hz}$. Presumed signals are the sum of individual returns from multiple radar pulses, which are subsequently stored. This substantially reduces the volume of data acquired. A vastly improved coherent radar depth sounder was developed with a new digital system incorporating 12 -bit A/D converters and field programmable gate arrays (FPGAs) to digitize and store the in-phase and quadrature signals with as few as 32 presumed returns for 1024 range cells at a pulse-repetition frequency of $9200 \mathrm{~Hz}$. Also, the new digital system performs preliminary processing and displays processed data in real time for the operator. This coherent radar depth sounder was first used routinely during the 1998 field season. The uncertainty of the radar ice-thickness measurements is within $\pm 10 \mathrm{~m}$ based on intercomparisons with icecore locations at both high-elevation interior sites and an outlet glacier (Gogineni and others, 2001).

Results of ice-sheet elevation surveys repeated after a 5 year period have shown that the ice sheet has thinned significantly in many areas along the margin of Greenland (Krabill and others, 2000). This thinning may be in part due to increased melting or decreased snowfall, but the magnitude of the change is so large that at least some of the thinning must be due to an increase in ice discharge down the outlet glaciers. Outlet glaciers play a major role in ice discharge and account for about half of the total mass loss from the ice sheet (Reeh and others, 1999). The important role of outlet glaciers in ice-sheet mass balance, and the recent results showing dramatic thinning have prompted a comprehensive assessment of outlet-glacier ice-thickness measurements 


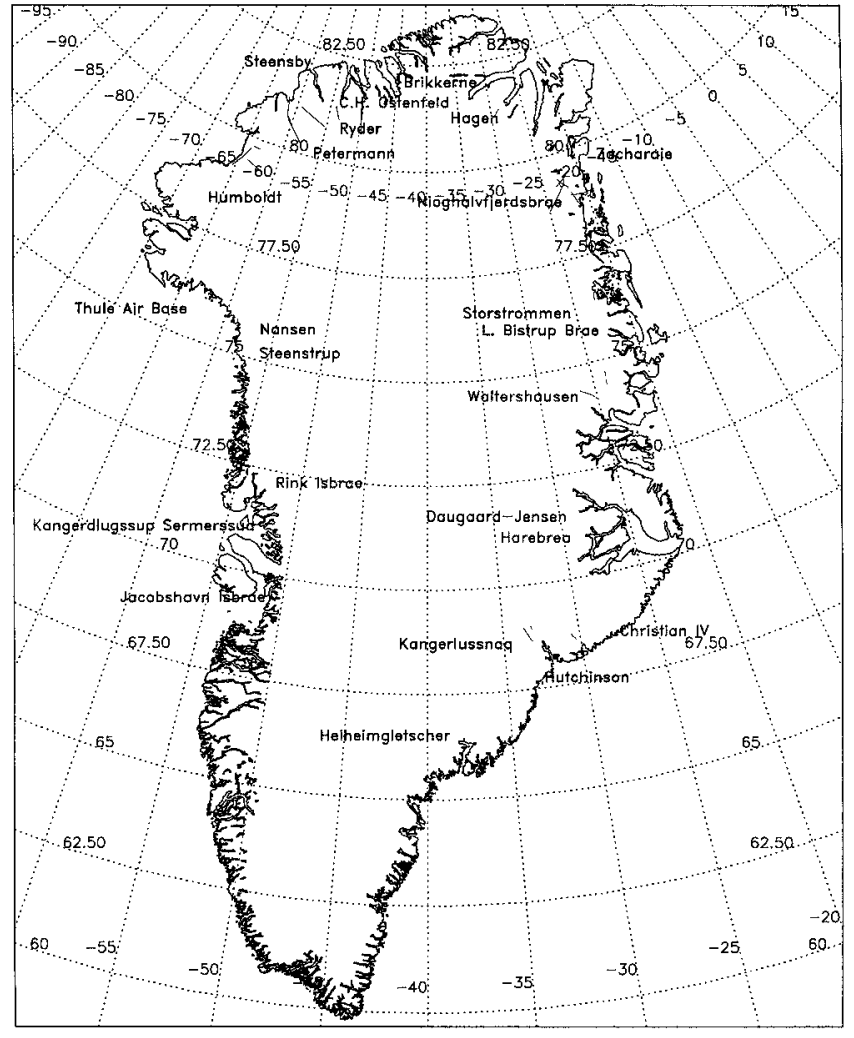

Fig. 1. Map showing the locations of outlet glaciers with available ice-thickness radar data.

obtained by the University of Kansas Radar Systems and Remote Sensing Laboratory (RSL) between 1993 and 1999, and during the latest flight surveys in 2001. These measurements are difficult to obtain due to warm ice conditions of many Greenland outlet glaciers, extremely rough surfaces due to heavy crevassing, and typically narrow terrain that confines the outlet glacier. Yet ice thickness is a critical and sensitive parameter in modeling glacier dynamics, where small errors in ice thickness can lead to large errors in modeling ice-discharge flux. The recent ice-thickness results will allow ice-sheet models to be updated with more detailed icethickness and bed geometry information.

In this paper, we summarize the ice-thickness data available for Greenland outlet glaciers and illustrate the improvement in radar sensitivity that has been gained by using a coherent radar and through the use of signal-processing techniques.

\section{ASSESSMENT OF IGE-THIGKNESS DATA}

All of the radar ice-sheet thickness measurements over and near outlet glaciers have been cataloged and examined to assess the quality and coverage of the data. Using kinematic GPS-derived positions of the radar ice-thickness measurements, flight paths over outlet glaciers were geolocated and plotted on high-resolution synthetic aperture radar (SAR) images (ERS-1) using the U.S. National Snow and Ice Data Center's (NSIDC) Large Image Map Browser (LIMB) software. These images allowed us to interpret the ice-thickness measurements with respect to exposed terrain and ice-sheet flowlines. Figure 1 shows the locations of the 23 outlet glaciers surveyed by one or more flights between 1993 and 2001, and Table 1 lists the locations of each glacier, the qual-
Table 1. Summary of ice-thickness data available for outlet glaciers surveyed by the University of Kansas radar depth sounder, 1993-2001

\begin{tabular}{lccc}
\hline Outletglacier & Location & Quality & Flight orientation \\
\hline Brikkerne Gletscher & $82.00^{\circ} \mathrm{N}, 45.00^{\circ} \mathrm{W}$ & Good & Trans. \\
C.H. Ostenfeld Gletscher & $81.75^{\circ} \mathrm{N}, 45.00^{\circ} \mathrm{W}$ & Good & Trans. \\
Christian IV Gletscher & $68.80^{\circ} \mathrm{N}, 30.40^{\circ} \mathrm{W}$ & Fair & Long. \\
Daugaard-Jensen Gletscher & $71.60^{\circ} \mathrm{N}, 29.70^{\circ} \mathrm{W}$ & Fair & Long. \& Trans. \\
Hagen Bræ & $81.50^{\circ} \mathrm{N}, 26.75^{\circ} \mathrm{W}$ & Good & Long. \\
Harebræ (Rodefjord) & $71.00^{\circ} \mathrm{N}, 29.00^{\circ} \mathrm{W}$ & Fair & Trans. \\
Helheimgletscher & $66.40^{\circ} \mathrm{N}, 37.50^{\circ} \mathrm{W}$ & Fair & Long. \& Trans. \\
Humboldt Gletscher & $79.50^{\circ} \mathrm{N}, 65.00^{\circ} \mathrm{W}$ & Good & Long. \& Trans. \\
Hutchinson Gletscher & $68.00^{\circ} \mathrm{N}, 32.00^{\circ} \mathrm{W}$ & Poor & Long. \\
Jakobshavn Isbræ & $69.20^{\circ} \mathrm{N}, 49.80^{\circ} \mathrm{W}$ & Good & Long. \& Trans. \\
Kangerdlugssûp sermerssua & $71.40^{\circ} \mathrm{N}, 51.00^{\circ} \mathrm{W}$ & Fair & Long. \\
Kangerlussuaq Glacier & $68.70^{\circ} \mathrm{N}, 33.30^{\circ} \mathrm{W}$ & Good & Long. \& Trans. \\
L. Bistrup Bræ & $76.50^{\circ} \mathrm{N}, 22.50^{\circ} \mathrm{W}$ & Good & Long. \\
Nansen Gletscher & $75.80^{\circ} \mathrm{N}, 58.70^{\circ} \mathrm{W}$ & Good & Trans. \\
Nioghalvfjerdsbræ & $79.50^{\circ} \mathrm{N}, 20.00^{\circ} \mathrm{W}$ & Good & Long. \& Trans. \\
Petermann Gletscher & $80.60^{\circ} \mathrm{N}, 60.00^{\circ} \mathrm{W}$ & Good & Long. \\
Rink Isbræ & $71.75^{\circ} \mathrm{N}, 52.50^{\circ} \mathrm{W}$ & Fair & Long. \\
Ryder Gletscher & $82.00^{\circ} \mathrm{N}, 51.00^{\circ} \mathrm{W}$ & Good & Long. \\
Steensby Gletscher & $81.50^{\circ} \mathrm{N}, 54.25^{\circ} \mathrm{W}$ & Good & Long. \\
Steenstrup Gletscher & $75.30^{\circ} \mathrm{N}, 57.00^{\circ} \mathrm{W}$ & Poor & Trans. \\
Storstrømmen & $77.10^{\circ} \mathrm{N}, 22.40^{\circ} \mathrm{W}$ & Good & Long. \& Trans. \\
Waltershausen Gletscher & $74.00^{\circ} \mathrm{N}, 24.50^{\circ} \mathrm{W}$ & Fair & Long. \\
Zachariæ Isstrøm & $79.00^{\circ} \mathrm{N}, 20.00^{\circ} \mathrm{W}$ & Good & Long. \& Trans. \\
& & & \\
\hline
\end{tabular}

Long., longitudinal orientation; Trans., transverse orientation.

ity of the data, and the orientation of the flight path with respect to the glacier flow axis. Several of these outlet glaciers (Jakobshavn, Kangerlussuaq and Helheim) were resurveyed during flights conducted during May 2001. We classified 14 of the outlet glaciers as having good ice-thickness data characterization, 7 with fair data and 2 with poor data. Our definition of good ice-thickness data is that the bedrock echo over the outlet glacier is distinct and, for longitudinal flights down or up the glacier, ice thickness is characterized to the calving front. A classification of fair indicates that the outlet-glacier survey contains gaps where the bedrock echo could not be resolved and, hence, continuous ice thickness has not been determined. These gaps generally occurred over deep glacier channels (due to signal absorption loss through thick, relatively warm ice), or in the relatively shallow ice zone near the calving front where the bedrock echo is sometimes obscured by off-vertical clutter from the very rough, crevassed surface, or by second multiple echoes of the ice surface. A classification of poor indicates that some ice-thickness data are available, but large, multiple gaps in the data occur along the flight path, primarily due to the high absorption loss in warm ice areas, the masking of the bottom echo by surface clutter, or both. All data with a distinct bedrock echo are made available to the scientific community in the form of radar echograms and derived ice thickness via the Internet from the University of Kansas (http://tornado.rsl.ukans.edu/Greenlanddata.htm).

\section{IMPROVEMENT OF RADAR SENSITIVITY USING A COHERENT RADAR}

The radar upgrade to a coherent detector and a data-acquisition system with the capability to digitize both in-phase and quadrature signals from the returned pulse has allowed the radar data to be further processed using SAR processing. 

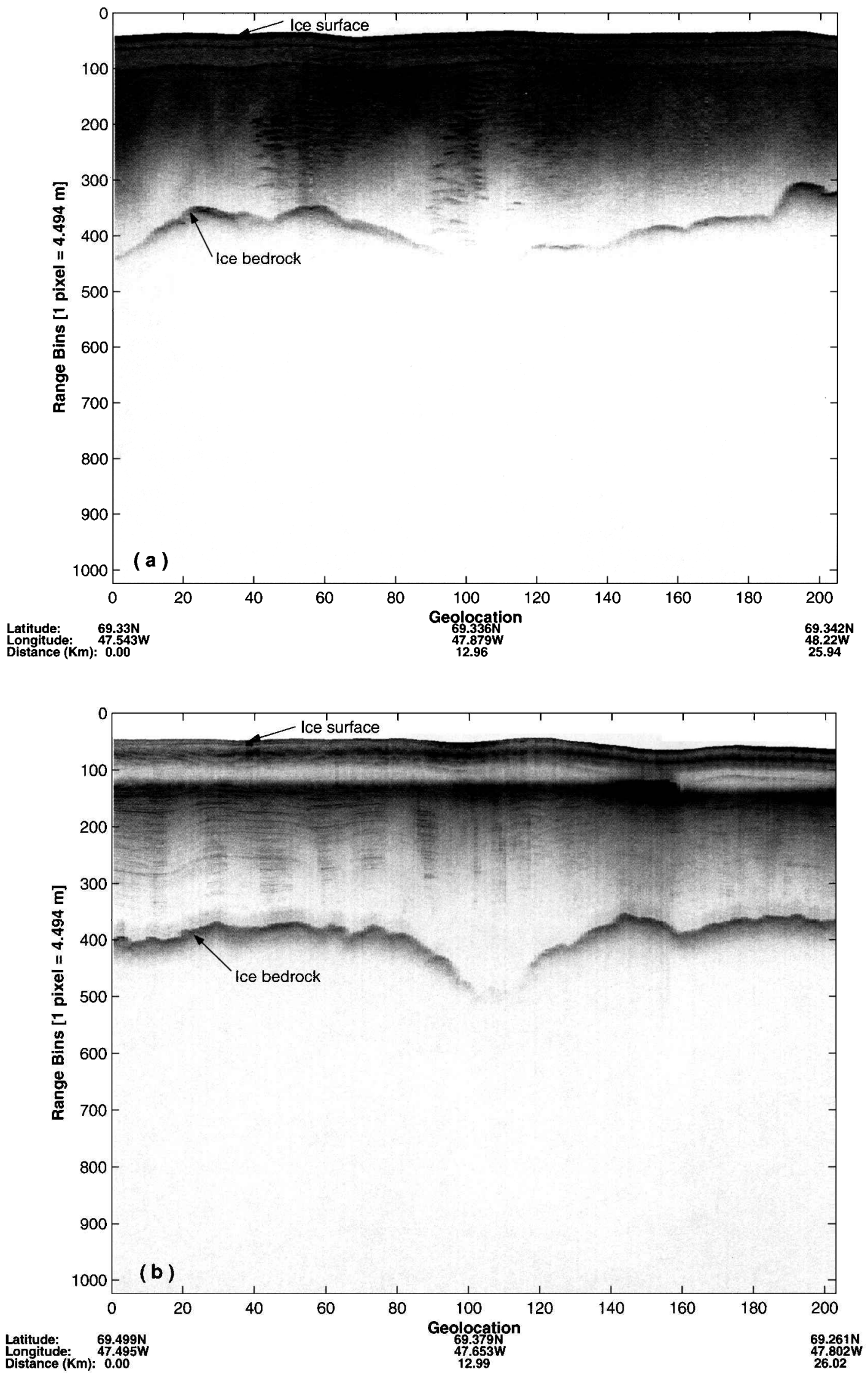

Fig. 2. Comparison of radar echograms from incoherent radar data collected on 13 May 1997 (a) and coherent radar data collected on 14 Fuly 1998 ( b ) over Jakobshavn Isbre. The incoherent data are unable to resolve the bottom in the channel, but with coherent data and SAR signal processing the channel bottom is seen. The vertical axis is given in range bins, where the ice thickness is the bottom range bin minus the top, multiplied by $4.494 \mathrm{~m} /$ range bin.

SAR processing can improve the signal-to-noise ratio enough to identify bed echoes that were previously obscured in the noise and reduces along-track off-vertical clutter. SAR processing is especially important in characterizing the ice thick- ness of deep, narrow outlet-glacier channels (e.g. Jakobshavn Isbræ) where signal absorption loss is higher due to relatively warm ice rather than the cold ice interior of the ice sheet.

An example of the signal improvement obtained from the 

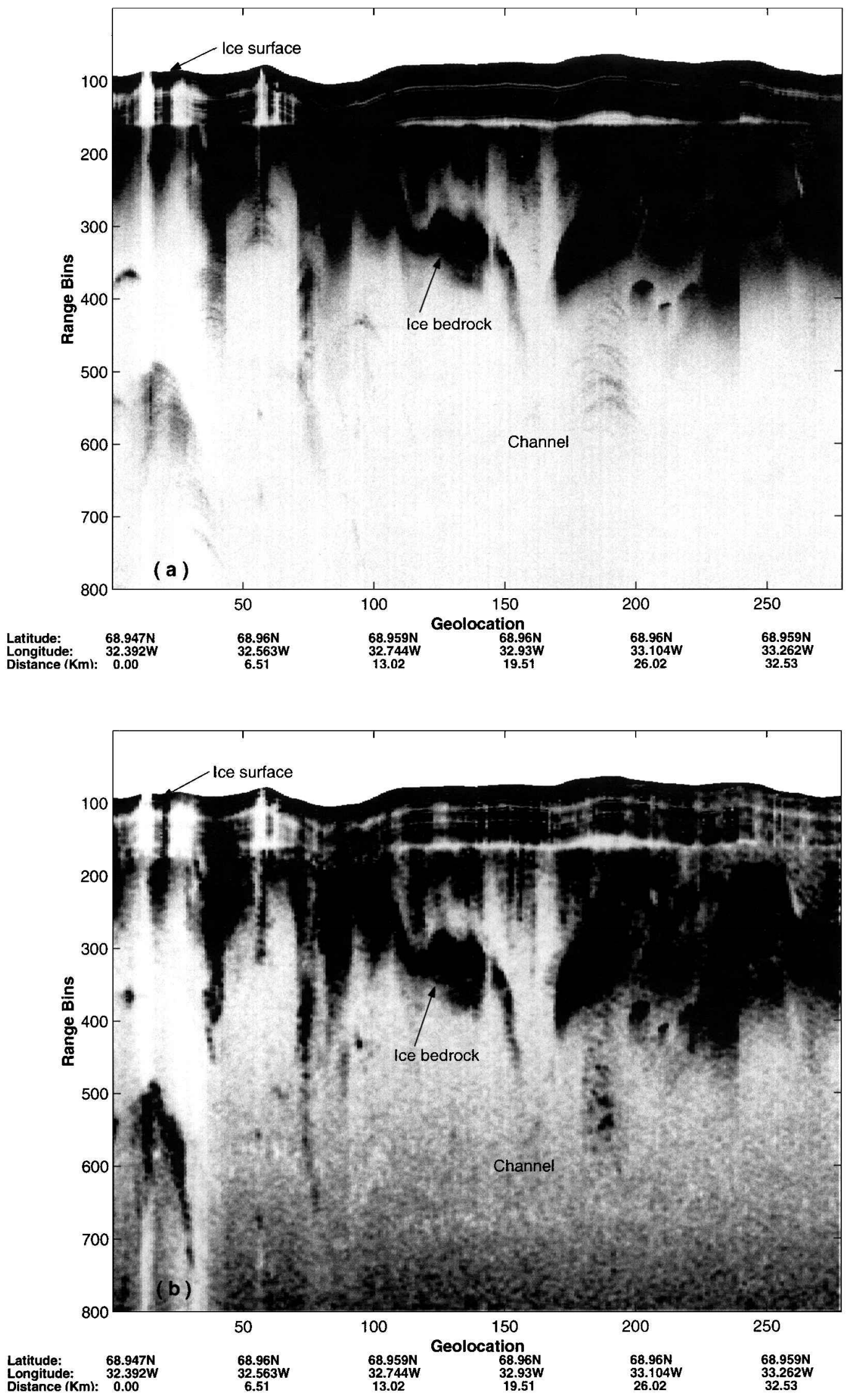

Fig. 3. Comparison of radar echograms from coherent radar data collected on 20 May 2001, over Kangerlussuaq Glacier: (a) the echogram represents the radar data with only basic signal conditioning procedures used to identify the bottom echo; (b) SAR processing is applied to these data revealing the bottom of the glacier channel. The vertical axis is given in range bins, where the ice thickness is the bottom range bin minus the top, multiplied by $4.494 \mathrm{~m} /$ range bin.

SAR-processed, coherent radar ice-thickness data collected in 1998, compared to the ice-thickness measurements using an incoherent ice-penetrating radar in 1997, is given in Figure 2a and b. Jakobshavn Isbræ was extensively surveyed during both years, allowing numerous intercomparisons of the coherent and incoherent data to be made where flight paths from both years were in close proximity. Figure $2 \mathrm{a}$ shows the radar echogram for a 13 May 1997, east-to-west crossing of the 

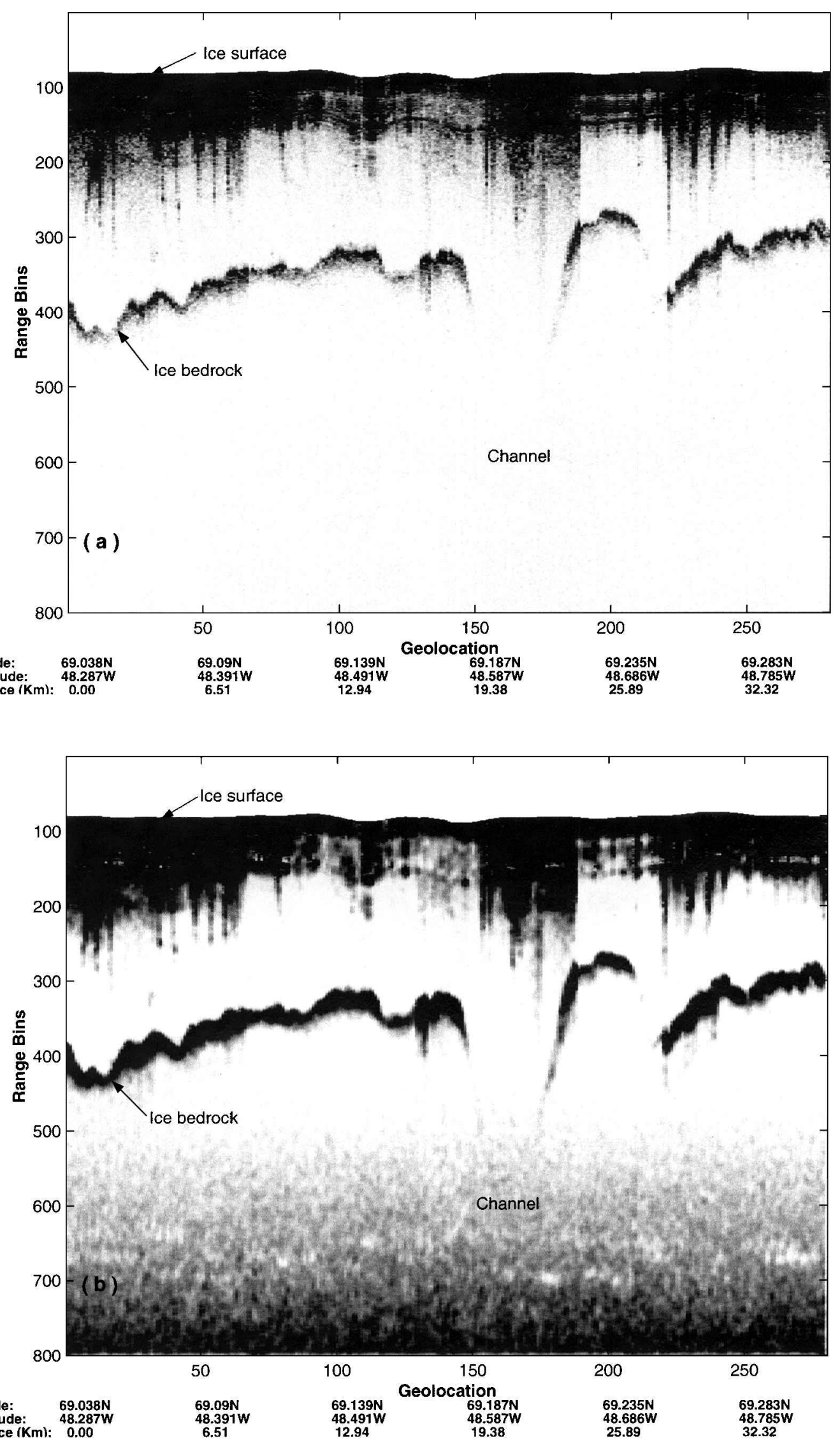

Fig. 4. Comparison of radar echograms from coherent radar data collected on 27 May 2001, over Jakobshavn Isbra: (a) the echogram represents the radar data with only basic signal conditioning procedures used to identify the bottom echo; (b) SAR processing is applied to these data revealing the bottom of the glacier channel. The vertical axis is given in range bins, where the ice thickness is the bottom range bin minus the top, multiplied by $4.494 \mathrm{~m} /$ range bin.

northern channel of Jakobshavn Isbræ at $69.34^{\circ} \mathrm{N}, 47.89^{\circ} \mathrm{W}$. The channel is aligned roughly southwest-northeast at this location, with each $x$-axis location number representing $1 \mathrm{~s}$ of averaged data, corresponding to a distance of approximately
$125 \mathrm{~m}$ and determined by the aircraft speed. Figure $2 \mathrm{a}$ is obtained from the incoherent radar and shows a clear bottom echo up to the glacier channel where the bottom echo disappears. At the point where the bottom echo disappears, the ice 
thickness is about $1850 \mathrm{~m}$. The bottom echo then reappears on the other side of the channel. In contrast, Figure $2 \mathrm{~b}$ is $\mathrm{a}$ coherent radar echogram with SAR signal processing applied to the data, showing a faint but distinct bottom echo in the channel at $2024 \mathrm{~m}$ depth. These data were obtained along a flight path crossing the glacier channel at $69.38^{\circ} \mathrm{N}, 47.65^{\circ} \mathrm{W}$ on 14 July 1998, with a heading of approximately $205^{\circ}$ (south-southwest). This was one of five separate channel crossings on three separate days in 1998 that were within $10 \mathrm{~km}$ of the 1997 channel crossing shown in Figure 2a. The average channel depth measured by the coherent radar for these five crossings was $2014 \mathrm{~m}$. It should also be noted that the coherent July 1998 data were collected in an ablation zone of the ice sheet under significant melt conditions, which caused larger signal attenuation (reducing the strength of the bed echo) than during the May 1997 measurements, which were collected before significant summertime melting began.

Recent flights to conduct ice-thickness surveys of the highpriority outlet glaciers, Jakobshavn Isbræ, Kangerlussuaq Glacier and Helheimgletscher, using the coherent radar depth sounder were carried out during May 2001. Signal conditioning and SAR processing have been applied to these data to remove d.c. offsets and reduce range side lobes. The SAR processing procedures apply conventional SAR processing in the along-track direction to the radar data, which generally increase the signal-to-noise ratio by several $\mathrm{dB}$.

During the May 2001 ice-thickness measurements of Jakobshavn Isbræ and Kangerlussuaq Glacier, SAR processing of the data permitted the deep outlet-glacier channels near the calving front to be mapped with an airborne radar. Figure $3 \mathrm{a}$ is an echogram for a flight segment over Kangerlussuaq Glacier on 20 May 2001, displaying radar data in which only signal conditioning has been applied. Over the outletglacier channel at approximately location 160, the bottom echo is lost in the noise. Each location number represents $1 \mathrm{~s}$ of averaged data, corresponding to distance of approximately $125 \mathrm{~m}$ and determined by the aircraft speed. After applying SAR processing techniques to the same conditioned radar data, the signal-to-noise ratio is increased by about $4 \mathrm{~dB}$, revealing a dim but distinct outline of the outlet-glacier channel (Fig. 3b). The maximum ice thickness of the Kangerlussuaq Glacier channel along this flight-line was measured to be $2204 \mathrm{~m}$.

For a flight segment down Jakobshavn Isbræ on 27 May 2001, the deep glacier channel is seen in the radar echograms at approximately location 160 in Figure $4 \mathrm{a}$ and b. Again, each location number represents 1 s of averaged data, corresponding to a distance of approximately $125 \mathrm{~m}$ that is determined by the aircraft speed. Only signal conditioning has been applied to the data shown in Figure 4a, and the bottom echo in the deep channel is lost in the noise. Figure $4 \mathrm{~b}$ shows the echogram after SAR processing has been applied. In this example, the signal-to-noise ratio has only been increased by about $1-2 \mathrm{~dB}$ as a result of SAR processing, yet this is sufficient to reveal the bottom of the channel dimly. The maximum ice thickness of the Jakobshavn Isbræ channel along this flight-line was measured to be $2192 \mathrm{~m}$.

\section{GONGLUSIONS}

A large volume of aircraft-based radar ice-thickness data has been collected over Greenland between 1993 and 2001 as part of the PARCA initiative. During this period, the radar depth sounder was incrementally upgraded to its present configuration as a highly versatile, coherent radar system capable of characterizing ice thickness over a wide variety of ice-sheet conditions. Ice thickness and bed geometry of Greenland outlet glaciers is of fundamental importance in understanding the ice-sheet response to climate change. For the outlet-glacier regions of Greenland, the available ice-thickness data collected through the PARCA program have been summarized. In some of these regions, large changes in ice-sheet elevation have recently been observed. Significant improvement in the signal-to-noise ratio and along-track spatial resolution has been achieved by collecting coherent radar data and processing these using SAR processing techniques. By applying SAR processing, the signal-to-noise ratio can be increased by a few $\mathrm{dB}$, allowing the bed echo from deep-outlet glacier channels to be resolved in some cases. This permits the ice thickness of outlet-glacier channels to be determined, allowing more accurate assessments of ice-sheet mass balance. These signal-to-noise ratio improvements are critical in outlet glacier-regions and in southern Greenland where warm ice increases the attenuation of the radar signal.

\section{ACKNOWLEDGEMENTS}

The work is supported by NASA grant No. NAG5-8758. We would like to thank C. Leuschen and P. Kanagaratnam for help with data processing and data collection. We would like to thank W. Krabill from the NASA Goddard Space Flight Center for providing surface elevation data, and R. Swift and J. Sonntag for planning the flights. We appreciate the skill and dedication of pilots W. Dykes and G. Pastel. The analyses of outlet glaciers presented in this paper benefited from the Digital SAR Mosaic of the Greenland Ice Sheet produced by M. Fahnestock (Department of Meteorology, University of Maryland, College Park, MD) and R. Kwok (Jet Propulsion Laboratory, California Institute of Technology, Pasadena, CA).

\section{REFERENCES}

Gogineni, S., T. Chuah, C. Allen, K. Jezek and R.K. Moore. 1998. An improved coherent radar depth sounder. F. Glaciol., 44(148), 659-669.

Gogineni, S. and 9 others. 2001. Coherent radar ice thickness measurements over the Greenland ice sheet. F. Geophys. Res., 106(D24), 33,761-33,772.

Krabill, W. B., R. H. Thomas, C. F. Martin, R. N. Swift and E. B. Frederick. 1995a. Accuracy of airborne laser altimetry over the Greenland ice sheet. Int. 7. Remote Sensing, 16(7), 1211-1222.

Krabill,W., R. Thomas, K. Jezek, K. Kuivinen and S. Manizade. 1995b. Greenland ice sheet thickness changes measured by laser altimetry. Geophys. Res. Lett., 22(17), 2341-2344.

Krabill, W. and 9 others. 2000. Greenland ice sheet: high-elevation balance and peripheral thinning. Science, 289(5478), 428-430.

Reeh, N., C. Mayer, H. Miller, H. H. Thomsen and A. Weidick. 1999. Present and past climate control on fjord glaciations in Greenland: implications for IRD-deposition in the sea. Geophys. Res. Lett., 26(8), 1039-1042. 